\section{Physical environment and life expectancy at birth in Mexico: an eco-epidemiological study}

\author{
Ambiente físico y esperanza de vida al nacer \\ en México: un estudio eco-epidemiológico
}

\author{
1 Instituto Nacional de Salud \\ Pública, Cuernavaca, México. \\ Correspondence \\ A. J. Idrovo \\ Instituto Nacional de Salud \\ Pública. \\ Av. Universidad 655, Col. Sta. \\ Ma. Ahuacatitlán, Cuernavaca \\ Morelos 62100, México. \\ javier.idrovo@insp.mx
}

\section{Abstract}

The objective of this ecological study was to ascertain the effects of physical environment on life expectancy at birth, using data from all 32 Mexican states. 50 environmental indicators with information about demography, housing, poverty, water, soils, biodiversity, forestry resources, and residues were included in exploratory factor analysis. Four factors were extracted: population vulnerability/ susceptibility, and biodiversity (FC1), urbanization, industrialization, and environmental sustainability (FC2), ecological resilience (FC3), and free-plague environments (FC4). Using OLS regressions, FC2, FC3, and FC4 were found to be positively associated with life expectancy at birth, while FC1 was negatively associated. This study suggests that physical environment is an important macro-determinant of the health of the Mexican population, and highlights the usefulness of ecological concepts in epidemiological studies.

Environmental Health; Environmental Pollution; Life Expectancy at Birth

\section{Introduction}

The association between physical environment and health has been known for a very long time. For example, changes in health introduced by agriculture and the Industrial Revolution are two milestones in this history ${ }^{1}$. Currently this association is more complex due to the prevalent social, cultural, and economic conditions. According to some estimates, environmental factors are responsible for $25-33 \%$ of the global burden of disease and mainly affect the under-five population 2.

Epidemiology, as a discipline studying the health of human populations, has been focused from its beginning on environmental effects on health. Even though many of its developments have focused on individual factors 3 , during the last decades a new interest in studying contextual effects on health has arisen 4 . In this way, the hegemonic approximation - so-called eco-social approach - has encouraged the study of social determinants 5 . Some effects of income inequality on health have been extensively explored within the "income inequality hypothesis" framework. Other macro-determinants require more empirical studies, following alternative approaches 6 .

The entwined relationships between social and physical environments are not yet fully understood. Donohoe 7 suggests that the combined action of environmental degradation and social injustice represent the most relevant macro- 
determinants of global health. These determinants are manifested in exaggerated increments in population growth, water and air pollution, deforestation, global warming, unsustainable agricultural and fishery practices, exaggerated consumption of goods, income inequality, economic crises, militarization and wars. As a consequence, various adverse conditions tend to worsen, including the extinction of some species, extreme weather conditions, growth in poverty, overcrowded living conditions, hunger, and human rights abuses. As can be appreciated, a reexamination of the effect of each of these determinants must be undertaken based on current knowledge.

Concepts from various environmental sciences and disciplines, mainly ecology, could help to understand the impact of each environmental factor on human health. However, their incorporation into epidemiological approaches demands high levels of creativity among researchers. There are few similar experiences available in the specialized literature. In the Latin American context the work of Josué de Castro and his followers are highly relevant because he proposed the existence of links between the physical and social environment to understand the current world ${ }^{8}$. It is very important to study this topic in Mexico since it is the country with one of the highest rates of deforestation in Latin America, despite the fact that it also one of the most biodiverse being one of the countries with largest biodiversity 9 . The objective of this study was to examine the potential effect of some physical environmental factors on life expectancy at birth.

\section{Material and methods}

\section{Design and sources of information}

An analytical ecological study with multiple groups 10 was carried out with data from the 32 Mexican states. Total and per sex life expectancy at birth were obtained for each state, from the 2003 registries of the National Institute of Statistics, Geography, and Informatics (Datos demográficos. http://wwwinegi.gob.mx/inegi/ default.asp, accessed on 15/Feb/2005), and the National Population Council (Conapo). Life expectancy at birth has been identified as a good marker of environmental health 11. Life expectancy at birth is a compositional variable defined as the mean number of additional years that a person would live if current mortality tendencies were maintained during his or her lifetime 12 . Given that life expectancy is strongly dependent on the criteria used to select groups, in regions with high child mortality life expectancy at birth is highly sensitive to deaths during the first years of life ${ }^{13}$. The relationship between mortality and life expectancy at birth has been recognized ever since a series of classic studies in the United Kingdom, where a historical reduction in mortality occurred at younger ages, and these changes were related to environmental changes 14 . It must be remembered that children are especially susceptible to environmental risk factors 2,15.

Environmental indicators included in the analysis are part of the Compendium of Environmental Statistics, and are available from the Environment and Natural Resources Ministry (Semarnat) web page (Compendio de estadísticas ambientales. http://www.semarnat.gob.mx/ wps/portal, accessed on 27/Sep/2004). In this text a complete description of each environmental indicator is available. Indicators were selected so that several of them could be included in each one of the following groups: (i) demography ( $\mathrm{n}=4)$; (ii) housing $(\mathrm{n}=3)$; (iii) poverty $(\mathrm{n}=6)$; (iv) water $(\mathrm{n}=4)$; (v) soils ( $\mathrm{n}=13$ ); (vi) biodiversity $(n=7)$; (vii) forestry resources $(n=6)$; and (viii) residues $(\mathrm{n}=7)$. Data originally in hectares (ha) were converted into kilometers $(\mathrm{km})$. Since there is no standard method to measure physical environment, these indicators were considered appropriate for building unmeasured latent variables with any dimensions of physical environment. The selected environmental indicators, with their respective abbreviations, included in the analysis were:

- Demography: total population in 2000 (D1), rural population in 2000 (D2), global rate of fecundity in 2002 (D3), and illiterate population aged 15 and above (\%) in 2002 (D4).

- Housing: individual dwelling-houses with plumbing (\%) (H1), individual dwelling-houses with sewage (\%) (H2), and individual dwellinghouses with electricity (\%) (H3). All data obtained from sources of 2002.

- Poverty: residences with certain overcrowding (\%) (P1), individuals occupying houses having compacted-soil floors (\%) (P2),marginalization index (P3), education level index (P4),gross national per capita income index (P5), and human development index (P6). All data obtained from sources for the year 2002.

- Water: mean annual rainfall between 1941 and 2000 (mm) (W1), extent of population with access to drinking water (\%) (W2), extent of population with access to sewage (\%) (W3), and disinfected water for human consumption as a percentage of the total supply (W4). All data obtained from 2002 sources.

- Soils: areas with trees (woods or tropical forests) (ha) (S1), areas with vegetation in arid zo- 
nes (ha) (S2), areas for agriculture (ha) (S3), areas for grasslands (ha) (S4), areas for human dwelling (ha) (S5), areas with mountainous regions (\%) (S6), wood ecosystem affected by modifying its use (\%) (S7), tropical forest ecosystem affected by modifying its use (\%) (S8), and dessert ecosystem affected by modifying its use (\%) (S9). All data obtained from 2002 sources. Additionally areas with degraded soils (ha) (S10), total areas without degradation (ha) (S11), and stabilized non-degraded lands due to human intervention (ha) (S12) from data obtained from 1999 sources; environmental emergencies occurred between 1995 and 2001 (\%) (S13).

- Biodiversity: registered fish species of the national total (\%) (B1), registered amphibian species of the national total (\%) (B2), registered reptile species of the national total (\%) (B3), registered bird species of the national total (\%) (B4), registered terrestrial mammals of the national total (\%) (B5), registered flying mammals of the national total (\%) (B6), and registered marine mammals of the national total (\%) (B7). Forestry resources: wood timber stock ( $\mathrm{m}^{3}$ in rolls) (F1) and tropical forest timber stock ( $\mathrm{m}^{3}$ in rolls) (F2) from 1994 data. Affected areas due to forest fires (ha) (F3), areas with forest diagnosis (ha) (F4), areas affected by plagues and forest diseases (ha) (F5), and areas under pest control and forest disease treatments (ha) (F6). The above came from 2001 sources.

- Waste: generation of municipal solid waste (thousands of tons) (R1), final disposal of municipal solid waste in sanitary landfills (thousands of tons) (R2), disposal of municipal solid waste in unsupervised sites and recycling (thousands of tons) (R3), population benefited with the collection of municipal solid waste (\%) (R4). All data obtained from 2001sources. Number of companies authorized in handling hazardous industrial waste in the year 2000 (R5), environmental risk studies in operating plants from 1992 to 2001 (R6), and environmental risk studies of new projects from 1992 to 2001 (R7).

\section{Statistical methods}

An exploratory factor analysis with 50 environmental indicators was carried out. This type of analysis was chosen to explore the effects of unmeasured latent variables from the physical environment. A previous study used a similar methodology to show its use in public health studies 16. Factor analysis is a mathematical model that explains covariance or correlation among a large number of observed variables in terms of a smaller group of unobserved latent variables 17 . One a priori criterion to consider a factor as relevant was that they exhibited a proportional contribution higher than 5\%. Four common factors (FC1, FC2, FC3, and FC4) were extracted after a varimax rotation. These factors explained $67.24 \%$ of the variance. In addition, factor scores were calculated for every state, and after these scores were normalized. A more detailed description of the remaining procedures of factor analysis is given in the Results section. These four factors were included as independent variables in OLS regressions where total and per sex life expectancy at birth were the dependent variables.

Subsequently, coefficients obtained were adjusted with Gini coefficients estimated using data from the 2000 national census, published elsewhere 18 . This index was included because in previous ecological studies, income inequality was shown to be a very important determinant of health among the Mexican population 19,20,21. During the exploration, the Gini coefficient was found to be included within the $\mathrm{FCl}$, thus this was excluded from further analyses. On the other hand, no normality was observed in studentized residuals; hence several models were tested in which the dependent variables were transformed. Nevertheless, results were rather similar; therefore, it was decided that the results were presented with the original variable to facilitate the interpretation. All analyses were performed with the Stata 11 statistical software (Stata Corp., College Station, USA).

\section{Results}

In 2003, life expectancy at birth in the overall Mexican population was on average 74.88 years, with a range from 73.2 to 76.1 years. Life expectancy at birth was higher for women (mean: 77.34 years, range: 75.9-78.5) than men (mean: 72.42 years, range: 70.6-73.9). The distribution of these variables were almost normal ( $p$-value $>0.05$, Shapiro-Wilk's test). Factor loadings of 50 environmental indicators for the four common factors are reported in Figures 1 to 4 . Eigenvalues for FC1, FC2, FC3, and FC4 were 15.89, 7.99, 6.86 , and 2.86, respectively, and the proportional contributions of these factors were $31.78,16.00$, 13.73, and 5.73.

The first factor (FC1) exhibited positive strong relations with marginality, population living in houses with compacted-soil floors, and illiteracy; other positive relations were with: rural population, global fecundity rate, overcrowding, historical rainfall, existence of tropical woodlands, and presence of amphibians, reptiles, birds and flying mammals. In addition, 


\section{Figure 1}

Factor loadings of factor 1 (FC1 - population vulnerability/susceptibility and biodiversity), extracted from 50 environmental indicators in the 32 Mexican federative entities *.

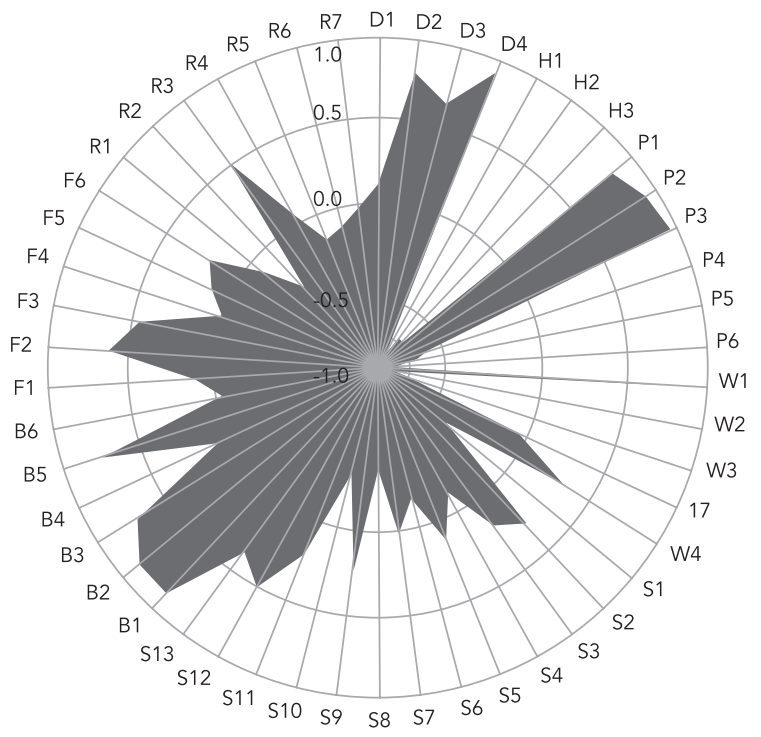

* Description of environmental indicators in the text.

Figure 2

Factor loadings of factor 2 (FC2 - urbanization, industrialization and environmental sustainability), extracted from 50 environmental indicators in the 32 Mexican federative entities *.

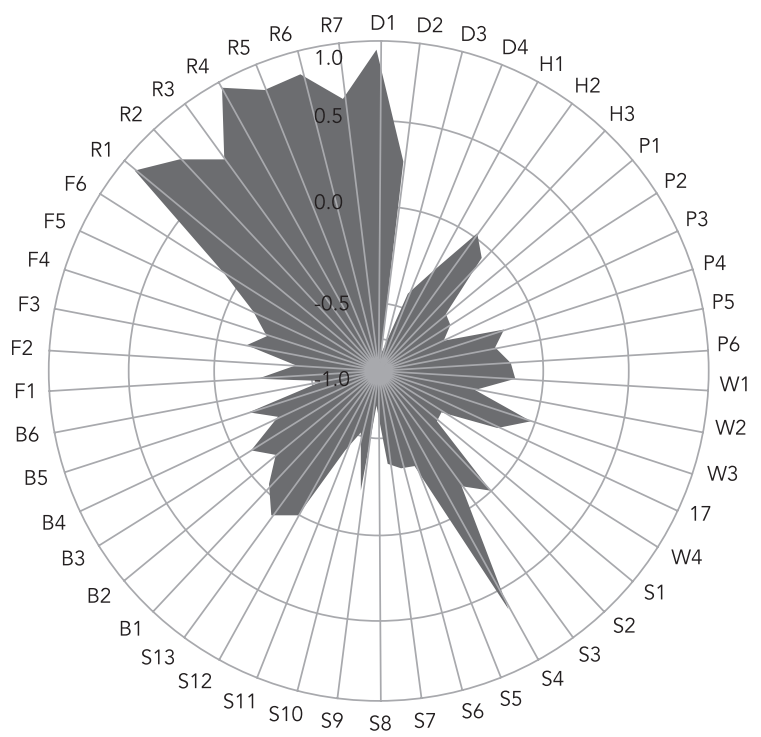

* Description of environmental indicators in the text. 
Figure 3

Factor loadings of factor 3 (FC3 - ecologic resilience), extracted from 50 environmental indicators in the 32 Mexican federative entities *.

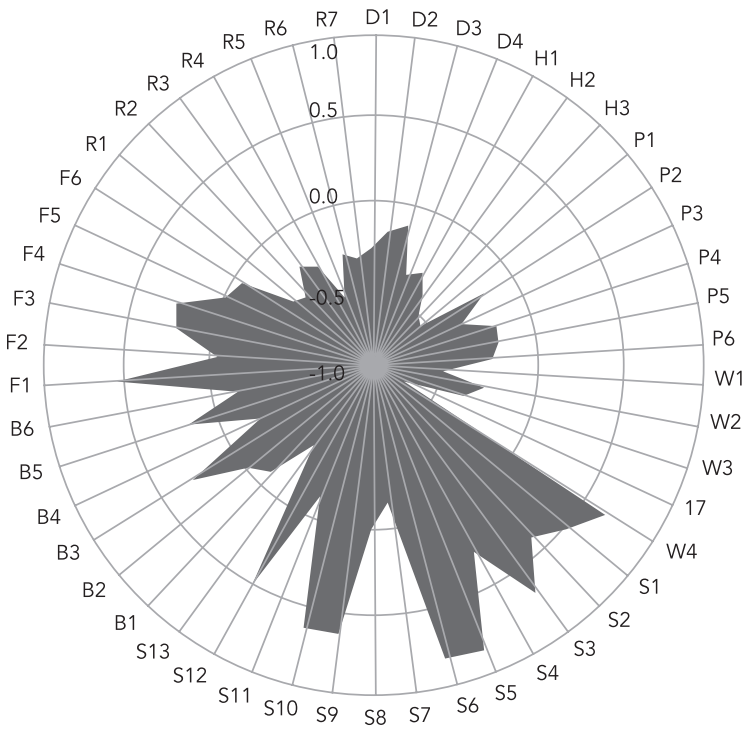

* Description of environmental indicators in the text.

Figure 4

Factor loadings of factor 4 (FC4 - environments free of forest plagues), extracted from 50 environmental indicators in the 32 Mexican federative entities *.

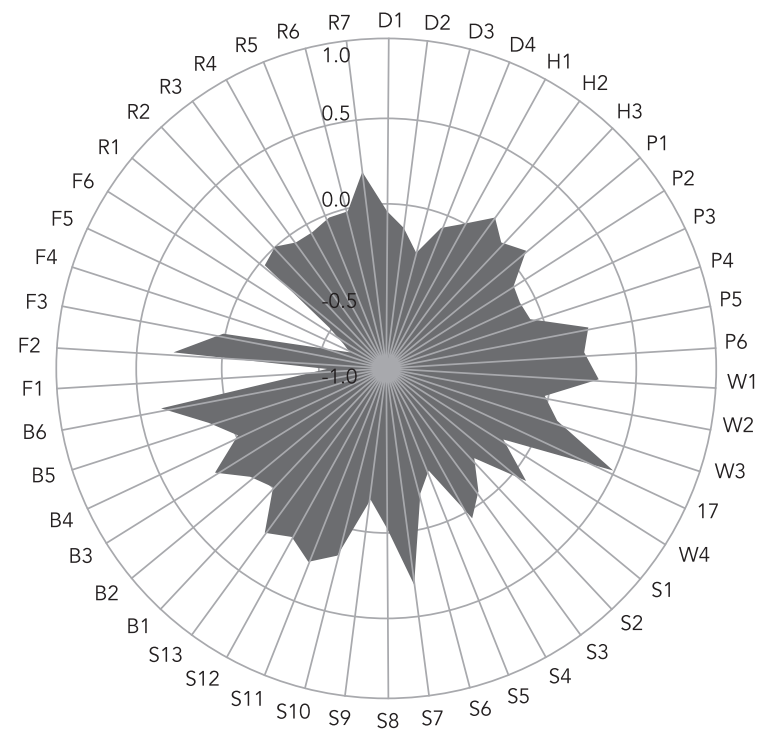

* Description of environmental indicators in the text. 
a strong negative association was present with the human development index, as well as with individual housing with plumbing, sewage, and electricity; educational level and gross national income per capita; population with drinking water and sewage. To this analysis this factor represented population vulnerability/susceptibility and biodiversity.

The second factor (FC2) has a strong positive relation with population benefited by solid waste collection, overall population, and generation of municipal solid waste. Likewise, a positive association was observed with areas predetermined for human dwelling, final disposal of municipal solid waste in sanitary landfills and unsupervised sites, and recycling, number of authorized companies handling hazardous industrial waste and environmental risk studies of industries in operation and new projects. In this analysis, this factor represented urbanization, industrialization, and environmental sustainability.

The third factor (FC3) was positively associated with areas having trees and vegetation in arid zones, area for grasslands, area with degraded soils, total area without apparent degradation and the existence of timberlands. This factor represented ecological resilience. The fourth factor (FC4) was negatively correlated to the existence of timberlands, area with forest diagnosis, areas affected by plagues and forest diseases. This factor encompassed environments free of forest plagues. The OLS regressions are summarized in Table 1 . Note that the four factors are significantly related ( $\mathrm{p}$-value $<0.05$ ) with life expectancy at birth, overall and per sex. FCl was negatively related for both sexes, though its impact was higher in women; conversely, FC2, FC3 and FC4 show a higher positive effect on men.

\section{Discussion}

A brief explanation will be given of the meaning assigned to each of the factors studied before addressing the results. Vulnerability has diverse meanings depending on the disciplinary approach. However, within health sciences it is frequently used to denominate health problems, harm or negligence; from this perspective, vulnerability is intimately related to the differential risk, either observed or expected, and enables the definition of vulnerable populations in reference to the enhanced susceptibility to adverse effects on health 22. Biodiversity is the degree of variety in nature in terms of genes, species, or ecosystems present in a determined region 23 . The relationship between diminished biodiversity and an increment in the occurrence of emergent and re-emergent infectious diseases has been described 24,25,26.

Urbanization is a social phenomenon characterized by the relative growth in the population residing in urban zones, along with underlying changes in inhabitants' lifestyles, food and the environmental factors in general to which such a population is exposed 27. Several studies describe the beneficial effects of urbanization related to the access to services concerning health, information, education, drinking water, larger incomes, while others report urban poverty associated with adverse effects due to overcrowding, inadequate water services and garbage disposal 28 . Industrialization is a series of social and economical changes by which a society is transformed from a pre-industrial phase to an industrial one. Its initial phase or proto-industrialization is characterized by a rapid development in rural industry with changes in the spatial organization of the rural economy; the appearance of machines is a distinctive trait of the second phase 29 .

Impact of environmental factors on life expectancy at birth estimated with multiple linear regression models.

\begin{tabular}{|c|c|c|c|c|c|c|}
\hline \multirow[t]{2}{*}{ Variable } & \multicolumn{2}{|c|}{ Total population } & \multicolumn{2}{|c|}{ Men } & \multicolumn{2}{|c|}{ Women } \\
\hline & $\beta$ & $95 \% \mathrm{Cl}$ & $\beta$ & $95 \% \mathrm{Cl}$ & $\boldsymbol{\beta}$ & $95 \% \mathrm{Cl}$ \\
\hline FC1 & -0.71 & $-0.76 ;-0.64$ & -0.80 & $-0.88 ;-0.72$ & -0.62 & $-0.68 ;-0.56$ \\
\hline $\mathrm{FC} 2$ & 0.14 & $0.07 ; 0.21$ & 0.14 & $0.06 ; 0.22$ & 0.13 & $0.07 ; 0.19$ \\
\hline FC3 & 0.07 & $0.00 ; 0.14$ & 0.09 & $0.01 ; 0.17$ & 0.06 & $-0.00 ; 0.12$ \\
\hline $\mathrm{FC} 4$ & 0.09 & $0.02 ; 0.16$ & 0.11 & $0.03 ; 0.19$ & 0.09 & $0.03 ; 0.15$ \\
\hline Adjusted $r^{2}$ & \multicolumn{2}{|c|}{0.9376} & \multicolumn{2}{|c|}{0.9344} & \multicolumn{2}{|c|}{0.9393} \\
\hline
\end{tabular}

FC1: population vulnerability/susceptibility and biodiversity; FC2: urbanization, industrialization and environmental sustainability; FC3: ecologic resilience; FC4: environments free of forest plagues; $95 \% \mathrm{Cl}$ : $95 \%$ confidence interval. 
Environmental sustainability refers to the actions taken to avoid a deterioration of the natural capital that supports human life ${ }^{30}$. It is an important consideration for all international organizations and, in a certain way, seeks to improve health conditions in human populations 31 . Ecologic resilience is the capacity of adaptation of an ecosystem when confronted with processes that alter its original state 32 ; a resilient environment is healthier that a degraded one 33 . Environments free of forest plagues may be related to better health conditions, taking into consideration the evidence that suggests that healthy plants and the conditions associated with the growth of crops are relevant indicators of human health, given the presence of environmental allergens, food security, agricultural practices, mycotoxigenic fungi and the biological control of diseases in plants ${ }^{34}$.

Having clarified the constructs for the four extracted factors, the more relevant finding in this study was the significant relation between life expectancy at birth and physical environment, expressed in the four factors studied. Among these, the one with the greatest impact was FC1, related to population vulnerability/susceptibility and biodiversity. The outcome of this study is consistent with previous studies, in which vulnerability is generally due to socioeconomic factors 35 though other forms of vulnerability and inequalities require further study 36,37 . The results showed a south to north gradient inverse to the tendency with life expectancy at birth. Latitudinal gradients such as these have been reported for multiple sclerosis 38 , some neoplasias 39 , Parkinson's disease 40 , and several infectious diseases 23 .

The second relevant finding was the combined presentation of the macro-determinants. In this manner the vulnerability/susceptibility factor cannot be isolated from biodiversity. These types of results have been previously reported 36,41 , though the emphasis in recent studies lies in poverty and income inequality rather than in their combined action. Possibly a fundamental cause may exist to account for these differences that is related to the so-called "inequality culture" 42 . This finding must be considered specific for Mexico and may not be generalized to other populations.

The positive association of life expectancy at birth and FC2, related to urbanization, industrialization and environmental sustainability may be,to a great extent, due to environmental sustainability. It is well known that chaotic urbanization and industrialization are associated with environmental degradation and this in turn is related to adverse health effects. Environmental degradation is considered to be due to the population effect, consumption level per person, and technology; these factors interact in diverse complex economical, political, social and cultural contexts 43,44 .

For this reason, the beneficial effects of urbanization and industrialization must be those related to environmental sustainability. FC3 and FC4 positive effects support the hypothesis that resilient environments are healthier, as well as those free of plagues, perhaps due to the previously mentioned mechanisms. The fact that FC3 is not associated with life expectancy at birth in women, though it is related to men and to both sexes taken together, could point to different causal mechanisms among men and women. These mechanisms need further study and might have not been detected if the analysis were not stratified per sex 45 .

These results are consistent with Castro's 46 arguments described in Geografia da Fome. $O$ Dilema Brasileiro: Pão ou Aço. Whereas in this study life expectancy at birth was the outcome, Castro analyzed the determinants of food insecurity. However it is very interesting that the complex relationship between physical and social environmentsare found to be relevant in both analyses. According to the book, originally published in 1946, a lack of nutrients in the food of Brazilian populations was a consequence of climatic and cultural characteristics of localities, and the concentration of land in the hands of few people ${ }^{47}$. The recognition of this relationship can help to delineate potential solutions to current nutritional and health problems. It may be necessary to change the hegemonic development options expressed in the "green revolution", to an "evergreen revolution" or "doubly green revolution" that is more respectful of nature 8 .

Results described here must be understood in light of the limitations of the methodology used. The present study is ecological, factors from the physical environment are global variables and the event is a compositional variable 10; so inferences at the individual level may lead to ecological fallacies. The associations encountered in this study are small, its magnitude agrees with the type of expected effects for ecological variables. The high correlation between variables, a methodological problem frequently found in ecological studies 10 , was corrected by the use of factor analysis 48 . The reduced sample size in this study may be a point of controversy. However, it is known that in factor analysis small samples allow for precise and accurate estimations when high communalities exist 49 , as in this study. The drawback of sample size turns to be more crucial in OLS regression; given that in the performed 
analyses significant relations were found, no problems of this type were faced.

In conclusion, this study suggests that contextual effects of physical environment impact on life expectancy at birth. The introduction of ecological concepts helped to understand the association between environment and health, in a similar manner in which these concepts have been used in other areas 50 . Further eco-epidemiological studies must favor the use of places as analysis units rather than geopolitical spaces 51 .
These studies should also improve the measurement of physical macro-environmental constructs, and incorporate variables with lower aggregation levels 52, including environments near to individuals (for example housing, work, and neighborhood). These design options enable a better identification of environmental effects. Likewise, other environmental factors should be explored, since each region possesses different ecosystems in which the relations between factors may vary.

\section{Resumen}

Para indagar los efectos del ambiente físico sobre la esperanza de vida al nacer se diseñó un estudio ecológico con datos de los estados mexicanos. Cincuenta indicadores ambientales con información sobre demografía, vivienda, pobreza, agua, suelos, biodiversidad, recursos forestales y residuos fueron incluidos en un análisis factorial exploratorio. Cuatro factores fueron extraídos: vulnerabilidad/susceptibilidad poblacional y biodiversidad (FC1), urbanización, industrialización y sustentabilidad ambiental (FC2), resiliencia ecológica (FC3) y ambientes libres de plagas (FC4). En regresiones lineales se observó que FC2, FC3 y FC4 se asociaron positivamente con la esperanza de vida al nacer, mientras FC1 estuvo asociado negativamente. Este estudio sugiere que el ambiente físico es un macro-determinante importante de la salud poblacional mexicana, y muestra la utilidad de los conceptos ecológicos en estudios epidemiológicos.

Salud Ambiental; Contaminación Ambiental; Esperanza de Vida al Nacer

\section{Acknowledgements}

I am indebted to Mauricio Hernández Avila, Ministry of Health, Mexico, and Héctor Duarte Taglés, Higher Studies Center of the State of Sonora (CESUES), for their very interesting suggestions and comments to an earlier version of this study. 


\section{References}

1. Barret R, Kuzawa CW, McDade T, Armelagos GJ. Emerging and reemerging infectious diseases: the third epidemiologic transition. Annu Rev Anthropol 1998; 27:247-71.

2. Smith KR, Corvalan CF, Kjellstrom T. How much global ill health is attributable to environmental factors? Epidemiology 1999; 10:573-84.

3. Pearce N. Traditional epidemiology, modern epidemiology, and public health. Am J Public Health 1996; 86:678-83.

4. Berkman LF, Kawachi I. Social epidemiology. Oxford: Oxford University Press; 2000.

5. Krieger N. Theories for social epidemiology in the 21st century: an ecosocial perspective. Int J Epidemiol 2001; 30:668-77.

6. Idrovo AJ, Ruiz-Rodríguez M, Manzano-Patiño A. Beyond the income inequality hypothesis: a worldwide exploration. Rev Saúde Pública 2010; 44:695-702.

7. Donohoe M. Causes and health consequences of environmental degradation and social injustice. Soc Sci Med 2003; 56:573-87.

8. Abramovay R. Integrar sociedade e natureza na luta contra a fome no século XXI. Cad Saúde Pública 2008; 24:2704-9.

9. Gómez-Pompa A, Kaus A. From pre-Hispanic to future conservation alternatives: lessons from Mexico. Proc Natl Acad Sci USA 1999; 96:5982-6.

10. Morgenstern H. Ecologic studies in epidemiology: concepts, principles, and methods. Annu Rev Public Health 1995; 16:61-81.

11. Gulis G. Life expectancy as an indicator of environmental health. Eur J Epidemiol 2000; 16:161-5.

12. McCann JC. A technique for estimating life expectancy with crude vital rates. Demography 1976; 13:259-72

13. Arriaga EE. Measuring and explaining the change in life expectancies. Demography 1984; 21:83-96.

14. Cutler D, Deaton A, Lleras-Muney A. The determinants of mortality. J Econ Perspect 2006; 20:97-120.

15. Landrigan PJ, Kimmel CA, Correa A, Eskenazi B. Children's health and the environment: public health issues and challenges for risk assessment. Environ Health Perspect 2004; 112:257-65.

16. Cummins S, Macintyre S, Davidson S, Ellaway A. Measuring neighborhood social and material context: generation and interpretation of ecological data from routine and non-routine sources. Health Place 2005; 11:249-60.

17. Widaman KF. Common factor analysis versus principal component analysis: Differential bias in representing model parameters? Multivariate Behav Res 1993; 28:263-311.

18. Tuirán-Gutiérrez R. La distribución del ingreso monetario en México. Este País, Tendencias y Opiniones 2003; (142):8-16.

19. Idrovo AJ. Desigualdad en el ingreso, corrupción y esperanza de vida al nacer en México. Rev Salud Pública (Bogotá) 2005; 7:121-9.

20. Idrovo AJ, Pérez-Núñez R. Determinants of occupational disease incidence in Mexico. Arch Environ Occup Health 2005; 60:299-301.
21. Idrovo AJ, Casique I. El empoderamiento de las mujeres y la esperanza de vida al nacer en México. Rev Panam Salud Pública 2006; 20:29-38.

22. Córdova-Contreras RJ, Idrovo AJ. Medición de la vulnerabilidad: el caso de la adicción a drogas ilícitas en Chihuahua, México. Región y Sociedad 2010; 22:239-63.

23. Martens P, Rotmans J, de Groot D. Biodiversity: luxury or necessity? Global Environ Change 2003; 13:75-81.

24. Guernier V, Hochberg ME, Guégan JF. Ecology drives the worldwide distribution of human diseases. PLoS Biol 2004; 2:740-6.

25. Dobson A, Carper R. Biodiversity. Lancet 1993; 342:1096-9.

26. McMichael AJ. Global environmental change and human population health: a conceptual and scientific challenge for epidemiology. Int J Epidemiol 1993; 22:1-8.

27. Phillips DR. Urbanization and human health. Parasitology 1993; 106 Suppl:S93-107.

28. McDade TW, Adair LS. Defining the "urban" in urbanization and health: a factor analysis approach. Soc Sci Med 2001; 53:55-70.

29. Mendels FF. Proto-industrialization: the first phase of the industrialization process. J Econ Hist 1972; 32:241-61.

30. Goodland R. The concept of environmental sustainability. Annu Rev Ecol Syst 1995; 26:1-24.

31. McMichael AJ, Butler CD, Folke C. New visions for addressing sustainability. Science 2003; 302: 1919-20.

32. Gunderson LH. Ecological resilience - in theory and application. Annu Rev Ecol Syst 2000; 31: 425-39.

33. Fiksel J. Designing resilient, sustainable systems. Environ Sci Technol 2003; 37:5330-9.

34. Scholthof KB. One foot in the furrow: linkages between agriculture, plant pathology, and public health. Annu Rev Public Health 2003; 24:153-74.

35. Cohen DA, Farley TA, Mason K. Why is poverty unhealthy? Social and physical mediators. Soc Sci Med 2003; 57:1631-41.

36. Boyce JK, Klemer AR, Templet PH, Willis CE. Power distribution, the environment, and public health: a state-level analysis. Ecol Econ 1999; 29:127-40.

37. Costa G, Marinacci C, Caiazzo A, Spadea T. individual and contextual determinants of inequalities in health: the Italian case. Int J Health Serv 2003; 33:635-67.

38. Forbes RB, Swingler RJ. Estimating the prevalence of multiple sclerosis in the United Kingdom by using capture-recapture methodology. Am J Epidemiol 1999; 149:1016-24.

39. Jones ME, Shugg D, Dwyer T, Young B, Bonett A. Interstate differences in incidence and mortality from melanoma. A re-examination of the latitudinal gradient. Med J Aust 1992; 157:373-8.

40. Lanska DJ. The geographic distribution of Parkinson's disease mortality in the United States. J Neurol Sci 1997; 150:63-70.

41. Macintyre S. The Black report and beyond what are the issues? Soc Sci Med 1997; 44:723-45. 
42. Wilkinson RG. The culture of inequality. In: Kawachi I, Kennedy B, Wilkinson RG, editors. The society and population health reader: income inequality and health. New York: The New Press; 1999. p. 492-8.

43. Holdren JP. Environmental degradation: population, affluence, technology, and sociopolitical factors. Environment 2000; 42:4-5.

44. Kates RW. Population and consumption. What we know, what we need to know. Environment 2000; 42:10-9.

45. Idrovo AJ. Hacia una epidemiología con enfoque de género. In: Sanín LH, editor. Género, salud y ambiente. Un paso a la integración. Chihuahua: Universidad Autónoma de Chihuahua; 2007.p. 227-48.

46. Castro J. Geografia da fome. O dilema brasileiro: pão ou aço. 10a Ed. Rio de Janeiro: Antares/Achiamé; 1980.

47. Vasconcelos FA. Josué de Castro e a geografia da fome no Brasil. Cad Saúde Pública 2008; 24:2710-7.
48. Mulaik SA. A brief history of the philosophical foundations of exploratory factor analysis. Multiv Behav Res 1987; 22:267-305.

49. McCallun RC, Widaman KF, Preacher KJ, Hong S. Sample size in factor analysis: the role of model error. Multiv Behav Res 2001; 36:611-37.

50. Díaz S, Cáceres DM. Ecological approaches to rural development projects. Cad Saúde Pública 2001; 17 Suppl:201-8.

51. Macintyre S, Ellaway A, Cummins S. Place effects on health: how can we conceptualise, operationalise and measure them? Soc Sci Med 2002; 55:12539 .

52. Susser E. Eco-epidemiology: thinking outside the black box. Epidemiology 2004; 15:519-20.

Submitted on $08 /$ Nov/2010

Final version resubmitted on 14/Mar/2011

Approved on 18/Mar/2011 